\title{
Structural study of a possible neoplasia detected in Mytilus galloprovincialis collected from the Ria of Vigo (NW Spain)
}

\author{
A. Alonso' ${ }^{1}$, P. Suarez ${ }^{2}$, C. Alvarez ${ }^{1}$, F. San Juan ${ }^{2}$, P. Molist ${ }^{1, *}$ \\ ${ }^{1}$ Department of Functional Biology and Health Sciences and ${ }^{2}$ Department of Biochemistry, Genetics and Immunology, \\ University of Vigo, Lagoas-Marcosende, 36200 Vigo, Spain
}

\begin{abstract}
Several specimens of Mytilus galloprovincialis, collected in the Ria of Vigo over a nonconsecutive 2 yr period (1993 to 1994 and 1996 to 1997), presented a possible gonadal neoplasm, entailing morphologically abnormal germinal cells distributed throughout the follicle and invading the adjacent storage tissue. In some cases, affected cells were noted in gonoducts and in haemic sinusoids. Prevalence of this anomaly in the samples was $6 \%$, and all affected individuals were found between April and June. During the rest of the year, individuals presented normal gonadal tissue.
\end{abstract}

KEY WORDS: Gonadal neoplasm · Histopathology $\cdot$ Structural study $\cdot$ Mytilus galloprovincialis Resale or republication not permitted without written consent of the publisher

\section{INTRODUCTION}

Mussel on the Galician coastline classified as Mytilus galloprovincialis (Sanjuan et al. 1989, Crespo et al. 1990) is an important species of commercial interest. Thus, matters concerning growth, reproduction and factors that may affect aspects of their biology are of particular interest. This species has 2 spawning periods in Galicia, one in autumn and another, of greater intensity, in spring (Aguirre 1979, Quintana 1986, Ferrán 1991). The presence of alterations in the germinal cells during the most important spawning period may affect reproductive success.

A tumour is defined as any swelling or abnormal mass of tissue that is characterised by autonomous uncontrolled growth (Sparks 1972). Over the past $20 \mathrm{yr}$, there has been an increase in research into tumours of invertebrates, since previously, it was considered that invertebrates were not susceptible to developing neoplasias (Engel 1930). Since then, an increasing number of tumours has been detected in these organisms.

\footnotetext{
*Corresponding author. E-mail: pmolist@uvigo.es
}

In bivalve molluscs, most identified neoplasms have been diagnosed as sarcomas of haematopoietic origin (Lauckner 1983, Peters 1988, Elston et al 1992, Bower et al. 1994, Rodriguez et al. 1997). This type of neoplasm has been associated with shellfish mortalities on the east and west coasts of the USA and Europe (Alderman et al. 1977, Appeldoorn \& Oprandy 1980). In Spain, particularly in Galicia, a similar case of haemocytic sarcoma has been reported (Gutiérrez \& Sarrasquete 1986). This may be considered as the first neoplasm described in Galician mussels. Other cases of haemocytic sarcomas have also been found in Ostrea edulis (Alderman et al. 1977), in Mytilus galloprovincialis (Figueras \& Montes 1988, Figueras et al. 1991) and in Ruditapes decussatus (Villalba et al. 1995).

In contrast, only a few gonadal germinomas have been reported in marine bivalve molluscs, mainly Mya arenaria (Yevich \& Barszcz 1976, 1977, Gardner et al. 1991, Peters et al. 1994, Barber 1996) Mercenaria spp. (Barry \& Yevich 1972, Hesselman et al. 1988) and 2 cases of germinoblastomas in Crassostrea virginica (Peters et al. 1994). In M. arenaria it has been shown that gonadal neoplasms have a negative impact on reproduction, decreasing the number of eggs produced per individual (Barber 1996). The relation be- 
tween sex and size (Hesselman et al. 1988, Bert et al. 1993, Barber 1996), season (Hesselman et al. 1988) and reproductive cycle (Ford et al. 1997) with the occurrence of gonadal neoplasia has been described.

In most cases of gonadal neoplasm, attempts were made to link occurrence with environmental contamination either from hydrocarbons (Barry \& Yevich 1975, Yevich \& Barszcz 1976, 1977, Brown et al. 1977) or herbicides (Gardner et al. 1991, van Beneden et al. 1993), as well as virus-like and unidentified infectious agents (Farley et al. 1972, Harshbarger et al. 1979, Ford et al. 1997) or even from biotoxins (Landsberg 1996). A genetic mechanism in the etiology of the disease has also been proposed (Bert et al. 1993, van Beneden et al. 1993). The etiology remains uncertain.

This paper reports for the first time the presence of a gonadal neoplasm in Mytilus galloprovincialis from the Ria of Vigo, Spain, and describes the occurrence of a seasonal and sexual prevalence. We also form a hypothesis about the possible etiology of this type of tumour.

\section{MATERIAL AND METHODS}

In this study we examined 850 males and females of Mytilus galloprovincialis collected from the same location in the Ria of Vigo (NW Spain) between June 1993 and July 1994, and between April 1996 and May 1997. Thirty individuals were collected in the first sampling and 10 in the second.

Samples were collected at 15 d intervals during the collection periods and they were taken of the same size (market size $7 \mathrm{~cm}$ long) and from approximately the same depth (0.5 to $1 \mathrm{~m})$.

In the Ria of Vigo, mussels are cultured on floating rafts. A raft consists of a system of floats to support the wooden grating from which mussels hang on lines.

Specimens collected from the same place on the raft were dissected in the laboratory, and the gonads were removed and fixed in Bouin's fluid. Subsequently, gonadal tissues were processed using routine histological techniques, sectioned at $5 \mu \mathrm{m}$ and stained with Mayer's haematoxylin and eosin. Additional slides were stained with the Masson trichrome method to visualise fibres of the connective tissue and with periodic acid-Schiff reaction counterstained with haematoxylin to show mucosubstances.

Small pieces of the gonads were fixed in $1 \%$ paraformaldehyde and $0.5 \%$ glutaraldehyde in cacodylate buffer, then postfixed in $1 \%$ osmium tetroxide, dehydrated in graded alco- hol and acetone, and embedded in Spurr's resin. Semithin sections $(0.7 \mu \mathrm{m})$ were stained with toluidine blue for examination with a light microscope.

The degree of disease developed in mussels was classified according to criteria defined by Peters et al. (1994) and Barber (1996): Stage 1, neoplasm comprising undifferentiated germ cells filling the lumens of 1 or more follicles; Stage 2, neoplasm is characterised by the presence of undifferentiated germinal cells in $50 \%$ of the visible follicles; Stage 3, all the follicles are invaded, losing their architecture, and the neoplasm is characterised by metastasis. Neoplastic cells appear in the vascular sinuses and blood vessels. Characteristically, intra- and extra-follicular fibrosis appears.

\section{RESULTS}

A total of 850 individuals were analysed, $6 \%$ of which presented pathological alteration in the development of germinal cells and were considered as gonadal neoplasms. In the individuals affected, we noted that the proportion of follicles with neoplastic characteristics was not constant, but rather ranged from individuals with all the follicles affected to those with a small proportion of altered follicles. Of the gonadal neoplasm, 32 cases were in Stage 1, 18 cases in Stage 2 and 5 cases in Stage 3. Gonads of both sexes were affected, but males were more likely than females to have neoplasms, the latter appearing only in sampling year 1993-94. This may have been because the number of individuals sampled in year 1993-94 was higher than in sampling year 1996-97 and because of the low prevalence of females (Fig. 1).

Gonadal neoplasms were found only between March and July for the first sampling, and from April to June for the second. The highest prevalences were noted at the start of spring, coinciding with an intense gametogenesis, and began to decrease in the early summer

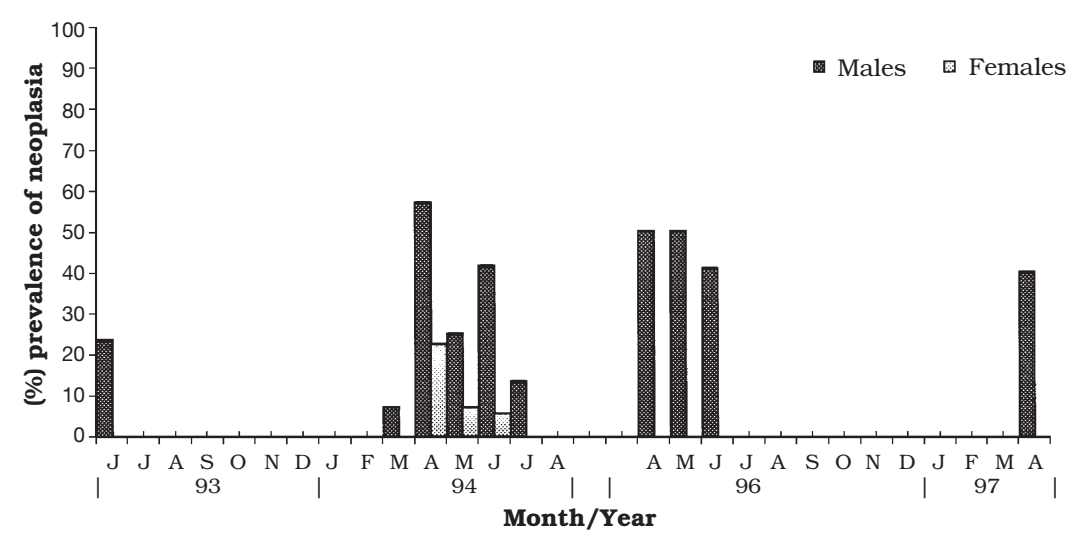

Fig. 1. Graph showing both monthly and sex prevalences of the gonad neoplasm 
Figs 2 to 4 . Gonad of male mussels showing abnormal cells invading adjacent tissues.

Fig. 2. Neoplastic cells inside the gonoduct (arrows), which show a ciliated epithelium. Haematoxylin and eosin stain. Scale bar: $20 \mu \mathrm{m}$

Fig. 3. Gonadal follicles showing the breach of the basal membrane and the infiltration of the neoplastic cells in the connective tissue (arrows). Masson trichrome stain. Scale bar: $100 \mu \mathrm{m}$

Fig. 4. Neoplastic cells inside a sinusoid (arrows). Haematoxylin and eosin stain. Scale bar: $20 \mu \mathrm{m}$
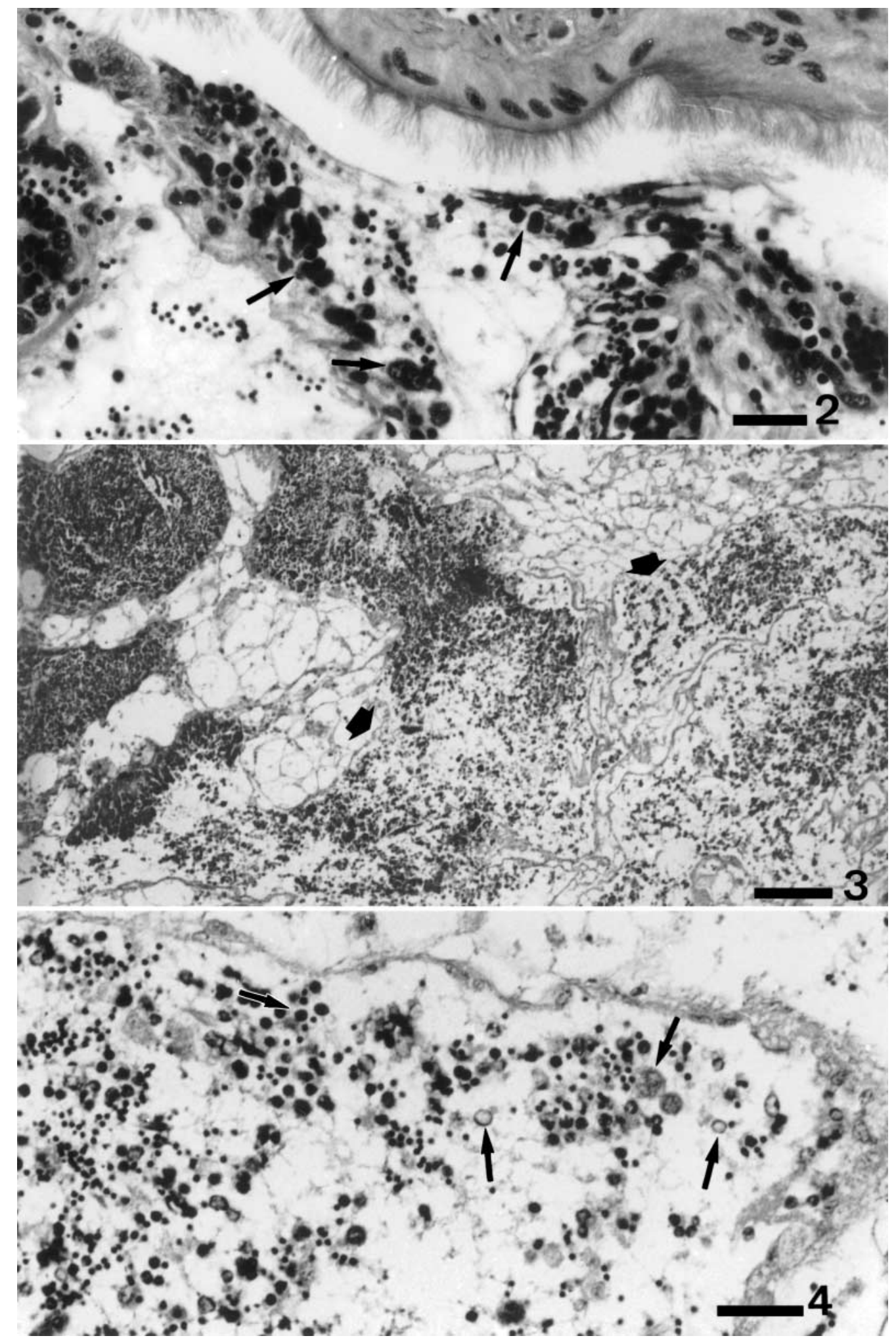

just before the main spawning period of Mytilus galloprovincialis off the Spanish coastline (Fig. 1). Mussels with heavy neoplasia (Stage 3) were present in April and May.
No gross abnormalities were recognisable in the neoplastic specimens, although histopathological analysis of the gonad tissue showed follicles filled with abnormal cells. The follicles in these individuals 


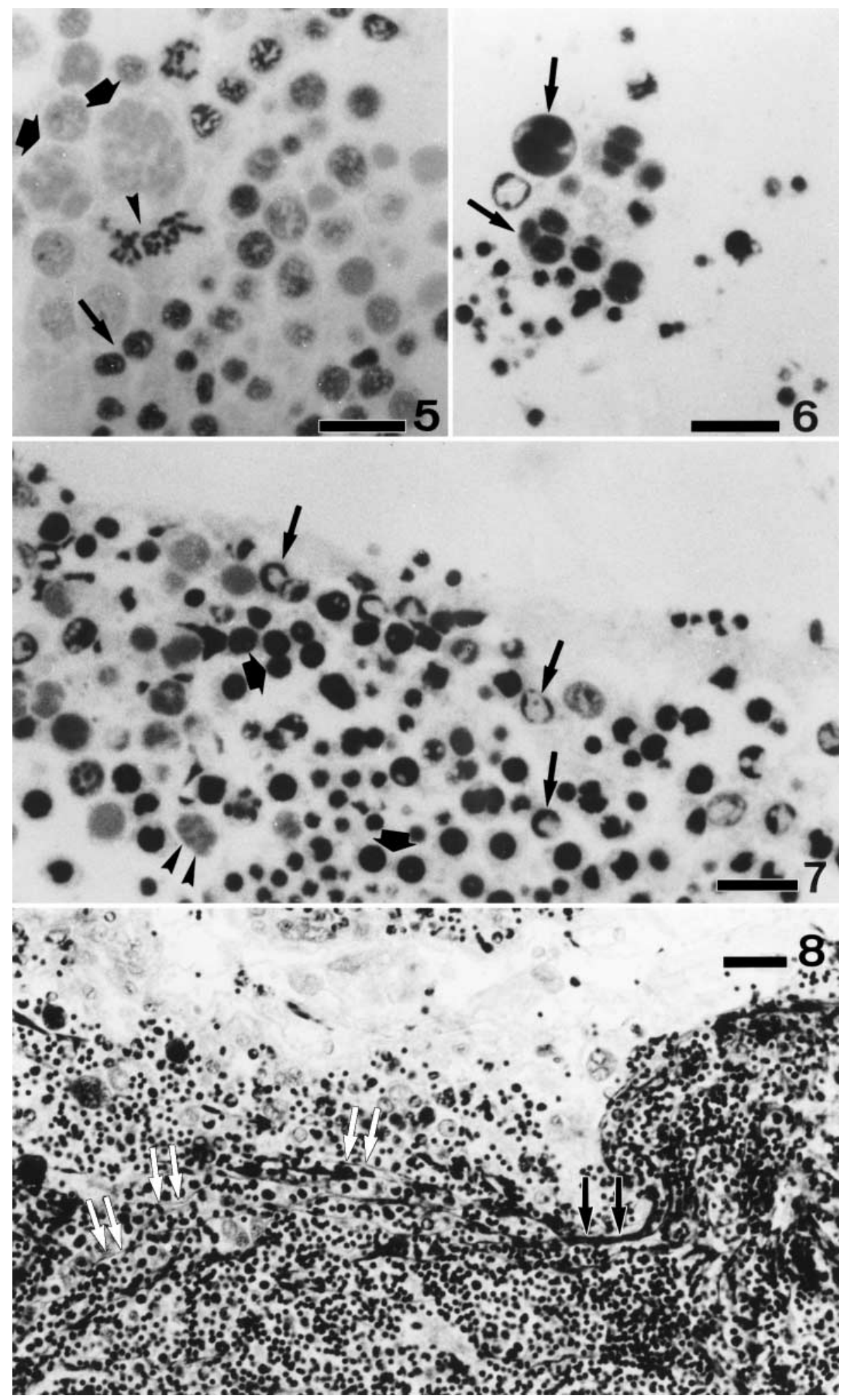

Figs 5 to 8. Gonadal folliccles of males with cell changes.

Fig. 5. Gonadal follicle affected by neoplasia showing cells with irregularly shaped chromatin (arrowhead), large mononucleated cells (arrow) and ghost cells (thick arrows). Semithin sections stained with toluidine blue. Scale bar: $10 \mu \mathrm{m}$

Fig. 6. Multinucleated cells showing 2 to 3 nuclei inside a gonadal follicle affected by the neoplasia (arrows). Semithin sections stained with toluidine blue. Scale bar: $10 \mu \mathrm{m}$

Fig. 7. The inside of a gonadal follicle affected by the neoplasia where it is possible to observe picnotic (thick arrows) and karriorhesis (arrows) nuclei, as well as ghost cells (arrowheads). Semithin sections stained with toluidine blue. Scale bar: $10 \mu \mathrm{m}$

Fig. 8. Intrafollicular fibrosis where it is possible to observe thick basophile (arrows) and thin eosinophile (white arrows) fibres. Masson trichrome stain. Scale bar: $20 \mu \mathrm{m}$

showed a heavy population of neoplastic cells, which emptied into the gonoducts being observed in their lumina (Fig. 2). In some cases, the basal membrane surrounding the follicles was breached and the follicu- lar cells infiltrated the adjacent connective tissue (Fig. 3). A heavy concentration of neoplastic cells was also found in vascular spaces (Fig. 4). In summary, a range of lesions was observed: in situ or intra-follicular 
neoplasia as well as infiltrating tumour, with features suggesting vascular invasion, which may be the means of metastatic dissemination.

The individuals affected had follicles with diverse degrees of cell changes where abundant mitotic figures were noted, some presenting a considerable increase in irregularly shaped chromatin (Fig. 5). We also found mononucleated and multinucleated hypertrophied cells that were larger than normal germinal cells. The nucleus of the mononucleated cells was often eccentric and the nucleolus was difficult to discern in the abundant, clumped chromatin; moreover, nucleus to cytoplasm ratios were high (Fig. 5). Multinucleated cells contained from 2 to 5 nuclei (Fig. 6). In addition, some cells showed pycnotic and sometimes karyorhesis nuclei (Fig. 7). Features of necrosis were observed with karyorhesis, karyolisis and ghost cells (Figs 5 \& 7).

Intra- and extra-follicular fibrosis was present in the neoplastic areas representing a desmoplastic reaction of the stroma around tumoural cells. The Masson trichrome stain revealed 2 types of fibres. Basophile fibres form thick walls between the germinal cells and the connective tissue, and in vessels and gonoducts. Eosinophile fibres, however, form a fine lattice between neoplastic cells (Fig. 8).

We noted no inflammatory lesion caused by any type of parasite, nor did we find any abnormal haemocyte invasion, although in specimens with follicles in Stages 2 and 3, individuals were found with a moderate to large profusion of haemocytes forming 'nodules' or dense groupings in the follicular lumen and gonoducts. Tentatively, we related this to a mechanism of eliminatory abnormal cells and to the recovery of the connective tissue of the gonad.

On the basis of these morphological characteristics of the neoplastic cells and their distribution in the tissue, we have considered this abnormal gonadal condition as a possible germinoma. We have found, however, that most of the affected gonadal follicles contained sperm or oocytes in all stages of normal maturation, which appears to indicate that not all germinal cells were affected.

\section{DISCUSSION}

Two types of gonadal neoplasms occur in marine bivalves. The first major type of proliferating gonadal disorder is called germinoma. The origin of this tumour is found in the germinal cells. The second type, reported in Crassostrea virginica (Peters et al. 1994), is termed gonadoblastoma, which suggests a more pluripotent cell of origin, a gonadoblast.

In this work, mussels collected directly from rafts located in the Ria of Vigo presented, from March to
July, a high percentage of gonadal disorders. Mammalian neoplastic cells have mainly 3 cytodiagnostic characteristics: anisokaryosis, nuclear hyperchromatism and anisocytosis (Lauckner 1983). Neoplastic cells of Mytilus galloprovincialis appear to share these diagnostic properties with mammalian cancerous cells.

Contrary to what occurs in mammals, in molluscs with an infiltrating tumour, some of the follicles contain not only altered germinal cells but also some final product of spermatogenesis, although the possible viability of these gametes and the normality of the subsequent embryonic and larval development remain to be determined. Molluscs, however, have a shorter life span, so the development of malignant neoplasms is a briefer process (Cheng 1993).

On basis of the traditional classification of tumours, we have considered this disorder as a gonadal neoplasm. Furthermore, this tumour appears to originate only in the germinal cells, so that we consider it to be a germinoma similar to those described in Mya arenaria (Yevich \& Barszcz 1977), Mercenaria mercenaria (Hesselman et al. 1988) or other mollusc species (Barry \& Yevich 1972, Hesselman et al. 1988, Peters et al. 1994).

Over the $2 \mathrm{yr}$ sampling period, the majority of the specimens affected presented a low percentage of follicles where alteration occurred in the germinal cells. A few individuals, however, also presented follicle breakage and invasion of the connective tissue. This suggests a progressive and potential lethal nature of the tumour (Barry \& Yevich 1975, Yevich \& Barzcz 1976, 1977, Peters et al. 1994), although in Mytilus this has not been shown. But if we take into account the presence of nodules of phagocytes during some stages of the disease, the absence of affected individuals for most of the year and prevalences of as much as $50 \%$ in certain months, we may hypothesise a possible recovery of some individuals. Remission of disseminated neoplasia has been hypothesised in molluscs with a low level of the disease (for revision see Elston et al. 1992).

The appearance of lesions only in certain months of the year leads us to consider that tumour development may be linked to environmental or environmental pollution factors affecting reproduction, since most of the lesions coincide with the most important spawning months. This fact may be associated with observations by the farmers of a gradual decrease in capturing spat from this mollusc, which is starting to affect the economic development of the sector.

The seasonal appearance of neoplasia has also been studied in Mercenaria spp. (Hesselman et al. 1988) where no strong relation has been noted between disease development and season. These authors found a correlation between water temperature and percentage of Mercenaria spp. with gonadal neoplasia. In our study, the appearance of neoplastic individuals is 
clearly related to the season. However, water temperature in the Ria of Vigo showed no annual fluctuations, maintaining an average value of 18 to $20^{\circ} \mathrm{C}$, so that this factor appears to be unimportant in terms of the appearance or progress of the disease.

The presence of gonadal neoplasm has often been linked with hydrocarbon pollution (Barry \& Yevich 1975, Yevich \& Barszcz 1976, 1977, Brown et al. 1977), but attempts to induce the disease by exposure to oilderived hydrocarbons proved unsuccessful (Carajaville 1991). In Mytilus galloprovincialis, exposure to low and intermediate doses of oil-derived hydrocarbons delays gamete release, but high doses induce spawning. Nevertheless, in none of the examined cases has the appearance of neoplasias in exposed mussels been proved (Cajaraville 1991). Other pollution factors, such as waste water and water for agricultural use (herbicides), have been associated with the presence of this type of pathology (Poole \& Arnold 1985), suggesting a chemical etiology for this disease. Therefore, the precise origin of this disease is still unknown.

We consider that the presence of individuals affected by the described germinoma only in the spring months may be due to a certain chemical contamination event. In both years the only contaminating event that coincided with the appearance of the tumour was probably linked with mussel raft cleaning and maintenance, these tasks being carried out according to climatic conditions, although generally conducted in early spring, just 15 to $30 \mathrm{~d}$ before the appearance of neoplasia. More detailed studies, however, should be conducted to confirm the possible carcinogenic effects of the chemical substances used in raft maintenance and their classification as steroidic xenobiotics.

The highest prevalence of this germinoma in males differs from that described in the literature cited by other authors, where this type of tumour has a higher frequency in females (Barry \& Yevich 1972, Yevich \& Barszcz 1976, Hesselman et al. 1988, Gardner et al. 1991, Bert et al. 1993, Barber 1996). There is support for the existence of a close relation between the sex of the individual and a hormonal disorder.

Acknowledgements. The authors thank Antonio Antepazos and the fishermen of the 'Antepazos I', who kindly provided the mussels used in this work. We are also grateful to Suso Méndez for technical assistance with histological preparations and to Ian Emmett for correcting the English of the manuscript. Thanks are also due to Drs José Antonio Ortiz and Ana de la Fuente at the POVISA Clinic Pathological Anatonomy Department for their assistance in interpreting the preparations, and to Dr Harshbarger for including specimens from this work in the Register of Tumours of Lower Animals, with numbers RTLA 7122-7127. This work was supported by a grant from the Autonomous Galician Government (Xunta de Galicia).

\section{LITERATURE CITED}

Aguirre P (1979) Biología del mejillón (Mytilus edulis) de cultivo de la Ría de Vigo. PhD thesis, Universidad Complutense, Madrid

Alderman DJ, Banning P, Pérez-Colomer A (1977) Two European oyster (Ostrea edulis) mortalities associated with an abnormal hemocytic condition. Aquaculture 10:335-340

Appeldoorn RSO, Oprandy JJ (1980) Tumours in soft-shell clams and the role played by a virus. Maritimes 24:4-6

Barber BJ (1996) Effects of gonadal neoplasms on oogenesis in softshell clams, Mya arenaria. J Invertebr Pathol 67:161-168

Barry MM, Yevich PP (1972) Incidence of gonadal cancer in the quahog Mercenaria mercenaria. Oncology 26:87-96

Barry MN, Yevich, PP (1975) The ecological, chemical and histopathological evaluation in oil spill sites. III: Histopathological studies. Mar Pollut Bull 6:171-173

Bert TM, Hesselman DM, Arnold WS, Moore WS, Cruz-López H, Marelli DC (1993) High frequency of gonadal neoplasia in hard clam (Mercenaria spp.) hybrid zone. Mar Biol 117: 97-104

Bower SM, McGladdery SE, Price IM (1994) Synopsis of infectious diseases and parasites of commercially exploited shellfish. Annu Rev Fish Dis 4:1-99

Brown RS, Wolke RE, Saila SB, Browun CW (1977) Prevalence of neoplasia in $10 \mathrm{New}$ England population of the softshell clam (Mya arenaria). Ann NY Acad Sci 298:522-534

Cajaraville MP (1991) Efectos histopatológicos y citotóxicos de los hidrocarburos derivados del petróleo, y su cuantificación en el mejillón Mytilus galloprovincialis (Lmk). PhD thesis, Universidad del País Vasco, Spain

Cheng T (1993) Noninfectious disease of marine molluscs. In: Couch JA (ed) Pathobiology of marine and estuarine organisms. CRC Press, Boca Raton, FL, p 319-342

Crespo CA, García Caballero T, Beiras A, Espinosa J (1990) Evidences from sperm ultrastructure that the mussel in Galician estuaries is Mytilus galloprovincialis (Lmk). J Molluscan Stud 56:127-128

Elston RA, Moore JD, Brooks K (1992) Disseminated neoplasia of bivalve molluscs. Rev Aquat Sci 6:405-466

Engel CS (1930) Warum erkranken wirbellose Tiere nicht an Krebs. Z Krebsforsch 32:531-543

Farley CA, Banfield WG, Kasnic G Jr, Foster WS (1972) Oyster herpes type virus. Science 178:759-760

Ferrán EJ (1991) Ciclo gonadal y tejido de reserva del mejillón de las rías de Galicia Mytilus galloprovincialis (Lmk). $\mathrm{PhD}$ thesis, Universidad de Santiago de Compostela, Spain

Figueras A, Montes J (1988) Parasites and diseases of mussel (Mytilus edulis and Mytilus galloprovincialis) cultivated on rafts in Galicia (NW Spain). $3^{\text {rd }}$ International Colloquium on Pathology in Marine Aquaculture, Gloucester Point, VA, p 95-96 (Abstract)

Figueras AJ, Jardón CF, Caldas JR (1991) Diseases and parasites of rafted mussels (Mytilus galloprovincialis Lmk): preliminary results. Aquaculture 99:17-33

Ford SE, Barber RD, Marks E (1997) Disseminated neoplasia in juvenile oysters Crassostrea virginica and its relationship to the reproductive cycle. Dis Aquat Org 28:73-77

Gardner GR, Yevich PP, Hurst P, Theyer P, Benyi S, Harshbarger JC, Pruell RJ (1991) Germinomas and teratoid siphon anomalies in softshell clams, Mya arenaria, environmentally exposed to herbicides. J Environ Health Perspect 90:43-51

Gutiérrez M, Sarasquete MC (1986) Un caso de haemocitosarcoma hialino en el mejillón Mytilus edulis L. (Pelecypoda: Mytilidae) de la costa NO de España. Inv Pesq 50:265-269 
Harshbarger JC, Otto SV, Chang SC (1979) Proliferative disorders in Crassostrea virginica and Mya arenaria from the Chesapeake Bay and intranuclear virus-like inclusions in Mya arenaria with germinomas from a marine oil spill site. Haliotis 8:243-248

Hesselman DM, Blake NJ, Peters EC (1988) Gonadal neoplasms in hard shell clams Mercenaria spp., from the Indian River lagoon Florida: ocurrence, prevalence and histophatology. J Invertebr Pathol 52:436-446

Landsberg JH (1996) Neoplasia and biotoxins in bivalves: is there a connection? J Shellfish Res 15:203-230

Lauckner G (1983) Neoplasia. In: Kinne O (ed) Diseases of marine animals. II (Mollusca). Bivalvia to Scaphopoda. Biologische Anstalt Helgoland, Hamburg, p 863-879

Peters EC (1988) Recent investigations on the disseminated sarcomas of marine bivalve molluscs. In: Disease processes in marine bivalve molluscs. Am Fish Soc Spec Publ 18:74-92

Peters EC, Yevich JC, Harshbarger JC, Zaroogian GE (1994) Comparative histopathology of gonadal neoplasms in marine bivalve molluscs. Dis Aquat Org 20:59-76

Poole BD, Arnold DW (1985) Shellfish survey of restricted and prohibited area classification in Brevard County, Florida. Florida Department of Natural Resources, Tallahassee

Quintana R (1986) Contribución al conocimiento del estroma

Editorial responsibility: Albert Sparks,

Seattle, Washington, USA gonadal del mejillón gallego cultivado. PhD thesis, Universidad de Santiago de Compostela, Spain

Rodriguez H, Soto M, Arias C, Estévez J (1997) A case of disseminated haemic sarcoma in Cerastoderma (Cardium) glaucum Poiret, 1789 collected from the Ria of Vigo (NW of Spain). Bull Eur Assoc Fish Pathol 17:88-90

Sanjuan A, Zapata C, Alvarez G (1989) On the occurrence of Mytilus edulis and M. Galloprovincialis in the Iberian peninsula as shown by allozyme polymorphisms. Proceedings of the International Symposium on Mussels, A Toxa, 6-10 November, Galicia, p 61

Sparks AK (1972) Tumors and tumorlike conditions in invertebrates. In: Invertebrate pathology. Academic Press, New York, p 271-371

van Beneden RJ, Gardner GR, Blake NJ, Blair DG (1993) Implications for the presence of transforming genes in gonadal tumours in two bivalve mollusc species. J Cancer Res 53:2976-2979

Villalba A, Peters EC, Lopez MC, Carballal MJ (1995) Disseminated sarcoma in the clam Ruditapes decussatus in Galicia (NW Spain). J Invertebr Pathol 65:76-78

Yevich PP, Barszcz CA (1976) Gonadal and haematopoietic neoplasms in Mya arenaria. Mar Fish Rev 38:42-43

Yevich PP, Barszcz CA (1977) Neoplasia in soft-shell clams (Mya arenaria) collected from oil-impacted areas. Ann NY Acad Sci 298:409-426

Submitted: June 13, 2000; Accepted: May 11, 2001

Proofs received from author(s): September 27, 2001 